\title{
Land taxation
}

\author{
Anca Marina IZVORANU \\ Institute of Agricultural Economics, Bucharest, Romania \\ ancaa.dinu@yahoo.com \\ Henriette Cristiana CĂLIN \\ Bucharest University of Economic Studies, Romania \\ henriette.calin@gmail.com
}

PICBE $\mid 883$

\begin{abstract}
The process of producing agricultural goods involves natural resources, cataloged as inputs. Neutral, the most important is the land, as the primary resource among seeds, land, agricultural machinery, fuel. The present paper will analyze how the land resource is taxed, the needs and opportunities of taxation, and what are the shortcomings of this niche. The study does not aim to deal exhaustively with the legislation related issues in this sector, but has in particular sought to identify future directions of development in terms of the ability of agricultural actors to cope with the commitments they have since they are owner of agricultural land. At the same time, the information resources landowners would need to help understand and overcome the tax obstacles that they live when they want to grow through acquisitions or expansions, will be considered. Taxes, as part of fiscal policy, part of the economic policy, are established instruments, considering the level of development and the state national economy. That's why they differ from one country to another, relative to their level of development. In low-developed countries, a smaller redistribution of the Gross Domestic Product of Taxes is observed, through the state budget, to the situation of the developed countries.
\end{abstract}

Keywords: land, taxation, agriculture, farms, Romania

\section{Introduction}

Recently, developing and transition countries have become more and more concerned with land and property taxes. Colombia is concerned about a possible reform of the taxation of rural property as an attempt to embrace the classical governing system, the rural environment under different forces (Garzón and VázquezCaro 2004). China is also involved in giving importance to land and property taxation for development in urban areas (Bird, 2005). From various motives, this concern is increasingly appearing on the political agendas of the world. From the taxation perspective, the capacity of the tax to participate in local budgets is very important, especially in decentralized countries where public funds are not so strong and they can provide additional revenue. In addition, the specialized literature suggests that land and property taxes can play a significant role in supporting social and institutional development, which is necessary for good governance and sustainable economic development (Sokoloff and Zolt 2005). This theme is widely addressed by economists around the world, however, this paper provides an overview of land taxation in Romania and covers two aspects: 1) the method by which land types are taxed and 2) the importance of land taxation as a local source of taxation to meet the financial needs of local governments. The paper concludes with some observations on the efficiency of land taxes compared to alternative forms of taxation. 


\section{Land taxes. An overview}

Starting with 2013, according to the Fiscal Code, any person who owns land located in Romania owes an annual tax, except for a few cases, such as:

- land owned by the state or territorial administrative units, except those used for economic or recreational purposes;

- land owned by the State in the private domain, concession, administration or leased property;

- the land of foundations for maintenance purposes, the development of national cultural institutions, as well as those for the purpose of supporting humanitarian, social and cultural activities;

- lands belonging to officially recognized religious denominations;

- the land on which there are cemeteries and crematories;

- land used by state educational establishments;

- the land plots of the sanitary units in the public domain, except for the carrying out of the economic activities;

- the terrain of hydropower systems, land related to port infrastructure and navigation;

- land used for flood defense activities;

- polluted or degraded land;

- lands that are unfit for agriculture and forestry;

- land with highways, European roads, national roads;

- the land intended for public railway infrastructure, respectively the metro;

- lands in industrial parks;

- the lands of the Romanian Academy;

- land of war veterans;

- forest areas.

Taxes on land are due to the local budget of the commune, town or city where it belongs or land is located. Local councils may decide to grant exemptions or reduce the tax for various types of natural disasters, land for retroceded buildings or land used for seasonal tourism, with a duration not exceeding 6 months.

\section{Calculation of tax}

The tax on the land is strayed considering the area of the land, the rank of the locality where it is located, the area and the category of its use, according to the rankings made by the local councils. For intangible land, which is registered under construction land, the tax is calculated by multiplying the area by the amount in Table 1.

Table 1. Level of tax on localities Intravillan - category of land use with construction - lei/ha -

\begin{tabular}{|l|l|l|l|l|l|l|}
\hline $\begin{array}{c}\text { The area } \\
\text { within the } \\
\text { locality }\end{array}$ & \multicolumn{6}{|l|}{ The ranks of the locality } \\
\hline & 0 & I & II & III & IV & V \\
\hline A & $8282-20706$ & $6878-17194$ & $6042-15106$ & $5236-13090$ & $711-1788$ & $569-1422$ \\
\hline B & $6878-17194$ & $5199-12998$ & $4215-10538$ & $3558-8894$ & $569-1422$ & $427-1068$ \\
\hline C & $5199-12998$ & $3558-8894$ & $2668-6670$ & $1690-4226$ & $427-1068$ & $284-710$ \\
\hline D & $3558-8894$ & $1690-4226$ & $1410-3526$ & $984-2439$ & $278-696$ & $142-356$ \\
\hline
\end{tabular}

Source: Romanian Fiscal Code, 2019 
For land intangibles, but for a different use category than land with construction, account shall be taken of the data in Table 2 and the amounts for the land use category and related areas, including a correction coefficient.

Table 2. Tax level by category of use and area Intravillan - other category of use other than land with construction - lei/ha-

\begin{tabular}{|c|l|c|c|c|c|}
\hline $\begin{array}{c}\text { Nr. } \\
\text { crt }\end{array}$ & \multicolumn{1}{|c|}{ Category of use } & A & B & C & D \\
\hline 1 & Arable land & 28 & 21 & 19 & 15 \\
\hline 2 & Pasture & 21 & 19 & 15 & 13 \\
\hline 3 & Grassland & 21 & 19 & 15 & 13 \\
\hline 4 & Vineyard & 46 & 35 & 28 & 19 \\
\hline 5 & Orchard & 53 & 46 & 35 & 28 \\
\hline 6 & Forest & 28 & 21 & 19 & 15 \\
\hline 7 & Land with water & 15 & 13 & 8 & 0 \\
\hline 8 & Roads and railways & 0 & 0 & 0 & 0 \\
\hline 9 & Unproductive land & 0 & 0 & 0 & 0 \\
\hline
\end{tabular}

Source: Romanian Fiscal Code, 2019

The correction coefficient mentioned above will be found in Table 3, which is used to calculate the tax on the land of the different category of the construction. The coefficient is determined by the rank of the locality and is taken into account alongside the surface, expressed in hectares and the corresponding amount. The rank of the locality is presented and described in the second column of the table below. Any type of land, from the one in the capital of the country to the one from municipalities, communes and villages, is considered. Each rank is defined according to the importance it has.

Table 3. The correction coefficient

\begin{tabular}{|c|l|c|}
\hline $\begin{array}{c}\text { The ranks of } \\
\text { the locality }\end{array}$ & \multicolumn{1}{|c|}{ Specification of rank } & Coefficient \\
\hline 0 & $\begin{array}{l}\text { refers to Bucharest, the capital of the country, } \\
\text { considered a city of European importance }\end{array}$ & 8,00 \\
\hline I & $\begin{array}{l}\text { refers to municipalities with national importance, but } \\
\text { with an existing influence at European level }\end{array}$ & 5,00 \\
\hline II & $\begin{array}{l}\text { refers to municipalities with inter-county or county } \\
\text { importance, having a role in the network of localities }\end{array}$ & 4,00 \\
\hline III & $\begin{array}{l}\text { cities } \\
\text { IV }\end{array}$ & $\begin{array}{l}\text { villages, residences of commune } \\
\text { villages, components of communes and villages } \\
\text { belonging to municipalities and towns }\end{array}$ \\
\hline V & \multicolumn{1}{|l}{} \\
\hline
\end{tabular}

Source: Romanian Fiscal Code 2019

The third category of land taxes, found in the Fiscal Code, refers to land located, both in the urban area and in the extravilan area in the category of land use, other than land with construction, for taxpayers, legal persons, which simultaneously fulfill the condition agricultural activity, as well as the recording of income and expenses from agricultural activity, in the accounting records, during the respective fiscal year. For this category, the sums used for the calculation of the land tax are those found in the table below, being 
constituted in a relative form which is definitively established by the local council of each village, commune, municipality, etc.

Table 4. Level of tax by category of use Inbound and outbound legal entities- lei/ha -

\begin{tabular}{|l|l|c|}
\hline \multicolumn{1}{|c|}{ Nr.crt. } & \multicolumn{1}{|c|}{ Category of use } & Tax \\
\hline 1 & Land with construction & $22-31$ \\
\hline 2 & Arable land & $42-50$ \\
\hline 3 & Pasture & $20-28$ \\
\hline 4 & Grassland & $20-28$ \\
\hline 5 & Grapevine on the fruit & $48-55$ \\
\hline 5.1 & Grapevine until the entrance to the fruit & 0 \\
\hline 6 & Livestock on the fruit & $48-56$ \\
\hline 6.1 & Livestock to the entrance & 0 \\
\hline 7 & Forest & $8-16$ \\
\hline 7.1 & Forest up to 20 years old & 0 \\
\hline 8 & Land with water, different from the one with fishing & $1-6$ \\
\hline 8.1 & improvements & $26-34$ \\
\hline 9 & Land with piscicultural improvements & 0 \\
\hline 10 & Roads and railways & 0 \\
\hline
\end{tabular}

Source: Romanian Fiscal Code, 2019

As a model of calculation, we will provide some examples of different areas and categories of use. We consider " $\mathrm{i}$ " the total sum of the acreage, "s" the area expressed in hectares, " $t$ " the level of the tax expressed in lei per hectare and "cf" the correction coefficient found in table 3. The "s" area will be expressed in "s1" for land with intravilan construction, "s2" for land with different destination than for intravilan construction, respectively "s3" for the lands of the legal entities from the town, respectively the lands outside the town with the object of agriculture.

Thus, for an intangible land, for the land use category, the calculation relation will be expressed as follows:

$$
\boldsymbol{I}=\boldsymbol{S}_{\mathbf{1}} * \boldsymbol{T} \text { (established by the local council) }
$$

For a land located in the urban area, but in a different category than land with construction, the calculation relation is:

$$
I=S_{2} * C f^{*} T
$$

And for the lands of the legal entities from the urban area, respectively the lands out of the agricultural field with the object of agriculture, the calculation will look like this:

$$
\boldsymbol{I}=\boldsymbol{S}_{3} * \boldsymbol{C} \boldsymbol{f} * \boldsymbol{T} \text { (established by the local council) }
$$

Case 1) For 0.1 hectars of built-up land in town, within a village of a commune (V rank locallity):

0.1 (hectare) * 569 (lei, according to a presumed decision of the local council) $=56.9$ lei

Case 2) For 2 hectares of arable land, located on the outskirts of a commune village (IV rank locallity): 
2 (hectares) $* 28$ (lei, supposed to be located in area A) X1,1 (rank of the locality) $=61,6$ lei

Case 3) For 10 hectares of vineyard on the outskirts, located within the radius of a town (III rank locallity place):

$$
10 \text { (hectares) } * 48 \text { lei } * 3 \text { (rank of the locality) }=1440 \text { lei }
$$

\section{Land as a source of government revenue}

The second part of the paper presents the rationale for land taxation, from the point of view of contributing to local budgets, but also from the point of view of the efficiency of land use. Taxation has not only fiscal but also non-fiscal, social. In many countries, land and property taxes are some of the oldest fees, which gives them an old and classic feature and a very difficult to modify.

\section{Current taxes on income and wealth}

Table 5. Local property tax -share of GDP (\%)

\begin{tabular}{|c|c|c|c|c|c|}
\hline Country & $\mathbf{1 9 7 0}$ `s & $\mathbf{1 9 8 0} \mathbf{3}$ & $\mathbf{1 9 9 0}$ `s & $\mathbf{2 0 0 0} \mathbf{s}$ & $\mathbf{2 0 1 0}$ ` \\
\hline Austria & 1.129 & 1.080 & 1.090 & 0.545 & 0.569 \\
\hline Belgium & 1.714 & 1.301 & 1.742 & 2.545 & 3.390 \\
\hline Czech Republic & $-{ }^{* *}$ & - & 0.47 & 0.422 & 0.473 \\
\hline Denmark & 2.320 & 2.120 & 1.752 & 1.764 & 1.846 \\
\hline Estonia & - & - & 0.37 & 0.282 & 0.297 \\
\hline Finland & 0.774 & 0.938 & 1.067 & 1.070 & 1.325 \\
\hline France & 1.729 & 2.303 & 2.986 & 3.292 & 3.968 \\
\hline Germany & 1.389 & 1.141 & 1.054 & 0.827 & 0.95 \\
\hline Greece & 1.765 & 0.76 & 2.211 & 1.587 & 2.786 \\
\hline Hungary & - & - & 0.52 & 0.74 & 1.188 \\
\hline Ireland & 2.836 & 1.402 & 1.505 & 1.937 & 1.652 \\
\hline Italy & 1.433 & 0.88 & 1.764 & 2.167 & 2.591 \\
\hline Latvia & - & - & 1.096 & 0.938 & 0.979 \\
\hline Lithuania & - & - & 0.39 & 0.383 & 0.323 \\
\hline Luxembourg & 1.723 & 2.268 & 2.819 & 3.151 & 3.020 \\
\hline Netherlands & 1.126 & 1.398 & 1.612 & 1.738 & 1.351 \\
\hline Poland & - & - & 1.325 & 1.487 & 1.335 \\
\hline Portugal & 0.539 & 0.41 & 0.352 & 1.148 & 1.191 \\
\hline Slovak Republic & - & - & 0.625 & 0.453 & 0.425 \\
\hline Slovenia & - & - & 0.651 & 0.602 & 0.622 \\
\hline Spain & 1.080 & 1.481 & 1.782 & 2.582 & 2.352 \\
\hline Sweden & 0.436 & 1.113 & 1.637 & 1.373 & 1.021 \\
\hline United Kingdom & 4.213 & 4.368 & 2.944 & 3.851 & 3.971 \\
\hline OECD (average) & 1.744 & 1.669 & 1.727 & 1.734 & 1.821 \\
\hline
\end{tabular}

*Data calculated by authors using the OECD database, https://data.oecd.org/tax/tax-on-property.htm; *Specifies that 2010 data refers to $2010-2017$;**For blank data 


\section{Objections}

The findings that land tax is a good way to increase the local budget have also been shared by big economists and in terms of land rent.

Ricardo confesses that "The rent tax would be the burden of the owners and could be moved to any class of consumers because there would be no difference between products from the most unproductive land and those of productive land" ("A tax on rent would fall wholly on landlords, and could not be shifted to any class of consumers - would leave unaltered the difference between the produce obtained from the least productive land in cultivation and that obtained from land of every other quality").

McCulloch confesses in note XXIV of "The Wealth of Nations" that "from the practical point of view, taxes on land rent are among the most unfair taxes" ("in a practical point of view taxes on the rent of land are among the most unjust and impolitic that can be imagined"), making this claim on the basis that it is almost impossible to distinguish the amount paid for the use of the land and the one paid for the expenses with it.

John Stuart not only is for all of the above admitted, but says the owners are not even entitled to take some money for land rent without having any risky and engaging affirmation that society has a natural right of belonging.

Mrs. Fawcett says in her husband's work"Political economy for beginners" that "The land tax, whether small or great in amount, partakes of the nature of a rent paid by the owner of land to the state. In a great part of India the land is owned by the government and therefore the land tax is rent paid direct to the state. The economic perfection of this system of tenure may be readily perceived."

\section{References}

Henry George, "Progress and Poverty", New York: Robert Schalkenbach Foundation, 1979

Karla Hoff, "Land Taxes, Output Taxes, and Sharecropping: Was Henry George Right?"

World Bank Economic Review, 5 (1991): 93-111.

Richard M. Bird and Enid Slack, "Land and Property Taxation", University of Toronto, March 2002

Richard M. Bird and Enid Slack, "Taxing Land and Property in Emerging Economies: Raising Revenue... and More?", University of Toronto, 2006

Mahmood Hasan Khan, "Agricultural taxation in developing countries: a survey of issues and policy", Canada, April 2000

Leif Jensen, "Property Tax in Romania Revision of development and implementation in the context of practices in EU and OECD countries", World Bank, 2014

P.K. Brown, M.A. Hepworth, "A Study of European Land Tax Systems", Lincoln Institute of Land Policy, 2002

ec.europa.eu

****Romanian Fiscal Code, 2019

$* * * *$ https://data.oecd.org/tax/tax-on-property.htm

****http://data.imf.org/?sk=E86E9088-3830-4CA3-B240-1B0EC5E15221 